\title{
Identification and molecular analysis of yeasts found in domestic pigeon droppings in Montes Claros, MG, Brazil
}

\author{
J. Santos ${ }^{1}$, M.A.S. Xavier ${ }^{1}$, L. Cardoso ${ }^{1}$, S.A.M Nobre ${ }^{2}$, R.R. Bacchi ${ }^{3}$, \\ C.H.C. Cangussu ${ }^{1}$, A.C. Almeida ${ }^{4}$, L.N. Leite ${ }^{1}$, N.A.P. Barreto ${ }^{1}$ and \\ A.R.E.O. Xavier ${ }^{1}$
}

${ }^{1}$ Centro de Ciências Biológicas e da Saúde, Departamento de Fisiopatologia, Programa de Graduação em Biotecnologia, Laboratório de Microbiologia, Universidade Estadual de Montes Claros, Montes Claros, MG, Brasil ${ }^{2}$ Centro de Ciências Biológicas e da Saúde, Departamento de Biologia, Laboratório de Controle Biológico e Epidemiológico, Universidade Estadual de Montes Claros, Montes Claros, MG, Brasil

${ }^{3}$ Centro de Ciências Biológicas e da Saúde, Departamento de Biologia, Laboratório de Microscopia, Universidade Estadual de Montes Claros, Montes Claros, MG, Brasil

${ }^{4}$ Instituto de Ciências Agrárias, Centro de Pesquisa em Ciências Agrárias, Laboratório de Saúde Animal, Universidade Federal de Minas Gerais, Montes Claros, MG, Brasil

Corresponding author: A.R.E.O. Xavier

E-mail: ericsson_aerc@yahoo.com.br

Genet. Mol. Res. 19 (1): gmr18521

Received November 16, 2019

Accepted March 11, 2020

Published March 26, 2020

DOI http://dx.doi.org/10.4238/gmr18521

\begin{abstract}
Pigeon droppings carry microorganisms such as Candida spp., which have high genetic variability and are the most common opportunistic pathogens in humans. There is a need to establish fast, reliable and simple laboratory methods to differentiate pathogenic from non-pathogenic yeast species in pigeon droppings, as they can be a source of contamination for humans. We examined yeasts isolated from domestic pigeon droppings through a proteomic approach using matrix-assisted laser desorption ionization (MALDITOF). We also examined genetic characteristics of the isolates by restriction fragment length polymorphism (RFLP) PCR and
\end{abstract}


enterobacterial repetitive intergenic consensus sequences PCR methods. Five colonies isolated from domestic pigeon droppings collected at three different sampling locations on the roof of a Brazilian university building were identified as Candida krusei and Candida rugosa by MALDI-TOF. Phylogenetic studies using the two PCR-based molecular methods were able to differentiate the species $C$. krusei and $C$. rugosa into different groups. These genomic methods gave similar results and proved useful for genetic diversity analysis and interspecific differentiation of Candida isolates.

Key words: Yeast identification; Molecular phylogeny; MALDI-TOF; ERIC-PCR; PCR-RFLP

\section{INTRODUCTION}

The role of pigeons and other birds as vectors of pathogens of public health importance, such as protozoa, fungi, yeast, bacteria and viruses, is well established. Among the microorganisms found in pigeon droppings are Cryptococcus neoformans and Candida species (Medina et al., 2011; Wu et al., 2012; Soltani et al., 2013; Dou et al., 2017; Xavier et al., 2019). Candida yeasts play an important role as environmental and industrial pollutants, causing fungal infections in humans (Medina et al., 2011; Gaskin et al., 2013).

Isolation and identification of fungi at the Candida species level are essential to ensure proper treatment, reduce the number of patients with invasive candidiasis and produce useful knowledge for further studies (Robledo-Leal et al., 2018). Candida species can be identified by phenotypic and genotypic assays. Phenotypic assays are suitable for characterizing the morphology of yeast colonies, while genotypic assays are generally based on DNA detection. The most commonly used molecular methods are conventional PCR, multiplex PCR, PCR-RFLP (restriction fragment length polymorphism) and real-time PCR (Mohammadi et al., 2015; Jafari et al., 2017). The most widely used and accepted gene regions as targets for molecular identification of yeasts are 18S rDNA, 5,8S rDNA and 28S rDNA. Among these genes are conserved regions of DNA known as internal transcribed spacer (ITS), also used as targets for species differentiation (Bellemain et al., 2010; Wu et al., 2012). The PCR-RFLP molecular method is based on DNA sequence variations present in electrophoretic band patterns after digestion by restriction enzymes (Bai, 2014). This method is useful for identifying Candida species since it is easy to perform, simple, economical, and fast (Mirhendi, 2006; Gharaghani et al., 2018). The PCR-RFLP technique is advantageous over other molecular techniques because it can discriminate and identify species such as Candida krusei and Candida rugosa (Fatima et al., 2017) Rapid screening of immunocompromised patients using the PCR-RFLP technique is useful for identifying the pathogen species and helps in guiding antifungal therapy (Isik et al., 2003).

Another method used in the characterization of bacterial species, fungi, bacteriophages, invertebrates, plants and vertebrates is the amplification of enterobacterial repetitive intergenic consensus sequences (ERIC), which is used in genetic, phylogenetic, taxonomic analysis and in epidemiological studies (Gillings, 1997). This method, known as PCR, is based on the amplification of genomic DNA fragments and is a highly 
discriminatory and reproducible method for molecular typing of microorganisms (Yuan, 2010; Chen, 2014).

Matrix-assisted laser desorption ionization (MALDI-TOF) mass spectrometry focuses on a proteomic approach and is useful in identifying yeasts with satisfactory results (Zhao et al., 2016; Dou et al., 2017). It is a fast, economical and accurate technique for fungal identification, favoring diagnosis in microbiological laboratories (Patel, 2015; Xavier et al., 2019). The objective of this study was to identify yeast species isolated from pigeon droppings and study their genetic characteristics.

\section{MATERIAL AND METHODS}

\section{Sample collection and presumptive yeast identification}

The study included samples of domestic pigeon (Columba livia) droppings collected from a $900 \mathrm{~m}^{2}$ public building of a public university in Brazil (16 $46^{\circ} 14^{\prime \prime} \mathrm{S}, 43^{\circ} 52^{\prime} 49^{\prime \prime} \mathrm{W}$ ), attended by nearly 1000 individuals per day including students, professors, administrative faculty staff, patients, and service providers. A single collection of pigeon stools was performed at 10 different locations on the roof of the building. These samples were stored in sterile plastic tubes and refrigerated at $4-8^{\circ} \mathrm{C}$ for $24 \mathrm{~h}$. A total of $0.5 \mathrm{~g}$ of each sample was weighed and suspended in $5 \mathrm{~mL}$ of $0.9 \%$ sterile sodium chloride solution. After vortexing for $3 \mathrm{~min}$ and settling for $30 \mathrm{~min}$ at room temperature, $100 \mu \mathrm{L}$ of the supernatant was removed and inoculated into Petri dishes containing Sabouraud's dextrose agar medium containing chloramphenicol $(40 \mathrm{mg} / \mathrm{L})$. The plates were incubated at $30^{\circ} \mathrm{C}$ for $48 \mathrm{~h}$. Presumptive colonies were identified as yeast after staining with methylene blue. For this study, five yeast colonies isolated from three different sampling locations were randomly chosen. These microorganisms were cryopreserved in aliquots containing BHI medium supplemented with $20 \%$ glycerol at $-20^{\circ} \mathrm{C}$ in a freezer.

\section{Yeast identification at the species level by MALDI -TOF}

Five cryopreserved colonies identified microscopically as presumptive yeast were reactivated in Sabouraud's dextrose agar medium added with chloramphenicol $(40 \mathrm{mg} / \mathrm{L})$ for $24 \mathrm{~h}$ at $30^{\circ} \mathrm{C}$. Samples were sent to the Laboratory of Diagnosis of Aquatic Animal Diseases of the Ministry of Agriculture, Livestock and Supply, University of Minas Gerais, Brazil to be identified to the species level following MALDI TOF protocol established by Assis et al. (2017).

\section{DNA extraction}

The cryopreserved isolates identified as C. krusei and C. rugosa were reactivated in Sabouraud's dextrose agar medium containing chloramphenicol $(40 \mathrm{mg} / \mathrm{L})$ for $24 \mathrm{~h}$ at $30^{\circ} \mathrm{C}$. For cell wall lysis and subsequent DNA extraction, a modified Doyle and Doyle (1990) protocol was used. Colonies were transferred to microtubes containing $5 \%$ lysis buffer [CTAB (cetyltrimethylammonium bromide), $100 \mathrm{mM}$ Tris $-\mathrm{HCl} \mathrm{pH} 8.0,1 \mathrm{mg} / \mathrm{mL}$ proteinase $\mathrm{K}, 20 \mathrm{mM}$ EDTA] and incubated in water bath at $70^{\circ} \mathrm{C}$ for $1 \mathrm{~h}$. Every $10 \mathrm{~min}$, the microtubes were removed from the water bath and manually inverted for rupture of the cell 
wall. For the extraction of DNA, a mixture of chloroform-isoamyl alcohol (24:1) was added to these microtubes and vortexed for $10 \mathrm{~min}$. Subsequently, the samples were centrifuged at $10,000 \mathrm{rpm}$ for $5 \mathrm{~min}$. The supernatant was transferred to a new tube, to which $10 \% \mathrm{CTAB}$ and isoamyl chloroform-alcohol (24:1) were added and vortexed for $10 \mathrm{~min}$. The samples were centrifuged at $10,000 \mathrm{rpm}$ for $10 \mathrm{~min}$. The supernatant was collected, and the nucleic acids precipitated with cold isopropanol for $24 \mathrm{~h}$ in $-20^{\circ} \mathrm{C}$ freezer. Microtubes containing the nucleic acids were centrifuged at $10000 \mathrm{rpm}$ for $5 \mathrm{~min}$ and the pellet was washed with $70 \%$ ethanol. The pellet containing the nucleic acids was resuspended in $20 \mu \mathrm{L}$ TE buffer $\left(10 \mathrm{mM}\right.$ Tris- $\mathrm{HCl}, \mathrm{pH} 8$ and $0.1 \mathrm{mM}$ EDTA), $2 \mu \mathrm{L}$ RNase $(10 \mathrm{mg} / \mathrm{mL})$ and stored at $-20{ }^{\circ} \mathrm{C}$. The DNA quality was assessed by $1 \%$ ethidium bromide agarose gel electrophoresis and gel images were taken.

\section{Gene profiling analysis using PCR-RFLP}

The ITS1 5'-TCCGTAGgTGAACCTGCG G-3' and LR7 5'TACTACCACCAAGATCT-3' universal fungal primers were used to amplify the entire internal transcribed spacer region (18S rDNA, 5.8S rDNA, 28S rDNA, ITS1 and ITS2; approximately 2000 base pairs) (Raja et al., 2017) from Candida species identified by MALDI-TOF. The reactions were carried out in a mix containing 2x Go Taq Green Master Mix ${ }^{\circledR}$ (Promega, Corporation, USA), $\mathrm{MgCl}_{2}(2.5 \mathrm{mM}), 10 \mu \mathrm{M}$ of each primer and $50 \mathrm{ng}$ yeast DNA in a final reaction volume of $50 \mu \mathrm{L}$. The PCR reaction was performed using an Applied Biosystems Veriti thermal cycler. The amplification conditions followed the following parameters: an initial denaturation cycle at $98^{\circ} \mathrm{C}$ for $30 \mathrm{~s}$ followed by 30 cycles of denaturation at $98^{\circ} \mathrm{C}$ for $10 \mathrm{~s}$, annealing at $54^{\circ} \mathrm{C}$ for $30 \mathrm{~s}$, extension at $72^{\circ} \mathrm{C}$ for $2 \mathrm{~min}$ and final extension at $72^{\circ} \mathrm{C}$ for $10 \mathrm{~min}$. The amplicons were examined on $1.5 \%$ agarose gel stained with ethidium bromide and images were taken.

For restriction analysis of PCR products, a total of $15 \mu \mathrm{L}$ of PCR products (containing approximately $500 \mathrm{ng}$ DNA) were digested with $10 \mathrm{U}$ HaeIII enzyme (TermoFisher Scientific), $2.5 \mu \mathrm{L}$ digestion buffer (10X), $1 \mu \mathrm{L}$ bovine serum albumin $(0.2$ $\mu \mathrm{g} / \mu \mathrm{L}$ ) and $5.5 \mu \mathrm{L}$ sterile water. The digestion system was incubated in a $37^{\circ} \mathrm{C}$ water bath for $2 \mathrm{~h}$. After the incubation period, $15 \mu \mathrm{L}$ of the restriction enzyme-digested PCR product was analyzed on $3 \%$ agarose gel stained with ethidium bromide and photo documented. The analysis of restriction profiles was performed visually by two observers and transformed into a binary data matrix, according to the presence (1) or absence (0) of bands. The genetic relationship evaluation among yeast isolates was performed according to Barbosa et al. (2019).

\section{Gene profiling analysis using ERIC-PCR}

Preserved primers ERIC-1 5'TGTAAGCTCCTGGGGATTAAC3' and ERIC-2 5'AAGTAAGTGACTGGGGTGAGCG3' for enterobacterial repetitive intergenic consensus sequences described in the literature (Duan et al., 2009) were used to characterize the genetic profile of Candida species identified by MALDI-TOF. The chemical and thermal PCR conditions were those described by Barbosa et al. (2019). The analysis of amplification profiles and genetic relationship among yeast isolates was performed according to Barbosa et al. (2019). 


\section{RESULTS}

In this study, five colonies isolated from pigeon droppings collected at three different sampling locations on the roof of a Brazilian university were characterized. The rationale of choosing locations at random was based on the purpose of this study, which is focused on standardizing methodologies for fast and accurate identification of pathogenic species and characterization of their genetic profiles. Therefore, proteomic and genomic approaches were used.

Microscopic analysis of the five colonies revealed that they are yeast eukaryotic cells (Figure 1A). Proteomic analysis identified them at the species level as C. krusei (3/5) and $C$. rugosa (2/5) (MALDI-TOF identification score $\geq 2000$ ) (Table 1).

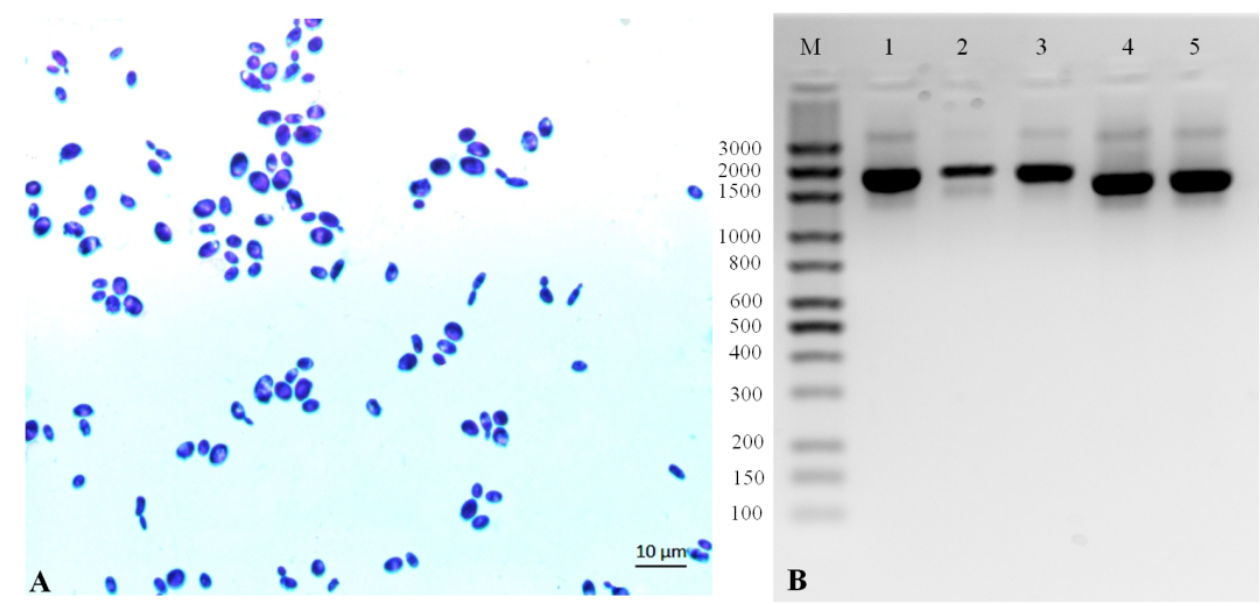

Figure 1. Microscopy and PCR analysis of the entire internal transcribed spacer region A. The colonies were subjected to the methylene blue staining procedure and visualized under a Nikon Eclipse E200 optical microscope at 1000X magnitude. B. PCR analysis with primers for the entire internal transcribed spacer region. M: Mid-range molecular weight marker (Cellco Biotechnology). Rows 1 to 5: Yeast isolates 1 to 5. The expected amplified fragment of approximately 2000bp corresponding to the entire internal transcribed spacer region is visualized on rows 1 to 5 .

Table 1. Phenotypic characterization, MALDI-TOF proteomic identification and genetic characterization of yeasts isolated from pigeon droppings collected February 2, 2018 from a roof.

\begin{tabular}{|c|c|c|c|c|c|c|}
\hline \multirow{2}{*}{ Isolate } & \multirow{2}{*}{$\begin{array}{l}\text { MALDI-TOF } \\
\text { Proteomic analysis }\end{array}$} & \multirow{2}{*}{$\begin{array}{l}\text { Genomic analysis of the entire } \\
\text { internal transcribed spacer } \\
\text { region } \\
\text { (2000 base pair fragment) }\end{array}$} & \multicolumn{2}{|c|}{$\begin{array}{l}\text { Genetic profile analysis } \\
\text { PCR-RFLP }\end{array}$} & \multicolumn{2}{|c|}{$\begin{array}{c}\text { Genetic profile analysis } \\
\text { ERIC-PCR }\end{array}$} \\
\hline & & & Group & Genotype & Group & Genotype \\
\hline ISO 1 & Candida krusei & + & I & I & I & I \\
\hline ISO 2 & Candida krusei & + & I & I & I & I \\
\hline ISO 3 & Candida krusei & + & I & I & I & I \\
\hline ISO 4 & Candida rugosa & + & II & II & II & II \\
\hline ISO 5 & Candida rugosa & + & II & II & II & II \\
\hline
\end{tabular}

In PCR-RFLP analysis, all isolates amplified a fragment of approximately 2000 base pairs corresponding to the entire internal transcribed spacer region (18S rDNA, 5.8S 
rDNA, 28S rDNA, ITS1 and ITS2 genes) (Raja et al., 2017) confirming the results of the microscopic analysis (Figure 1B and Table 1.) PCR products from this region were subjected to digestion with HaeIII restriction enzyme to evaluate the efficiency of the PCRRFLP method in detecting inter and intraspecific genetic variability among isolates. The three isolates identified as $C$. krusei showed the same digestion profile, where 50, 125, 250, 290, 390 and 550 base pair (bp) bands were visualized on a 3\% agarose gel (Figure 2A). The two isolates identified as $C$. rugosa had different profiles compared with the C. krusei species. However, C. rugosa species shared the same band pattern (100, 140, 500 and 800 base pairs) (Figure 2A). For the band sharing analysis, bands in the range of 50-800 bp were considered. The binary matrix created upon visual observation of the presence or absence of the fragments obtained after conduction of cluster analysis/calculation of the Euclidean distance generated a dendrogram showing the genetic diversity among isolates. The five isolates were divided into two groups (Group I and II) and distinct genotypes (Genotype I and II) according to the degree of similarity (Figure 2B and Table 1).
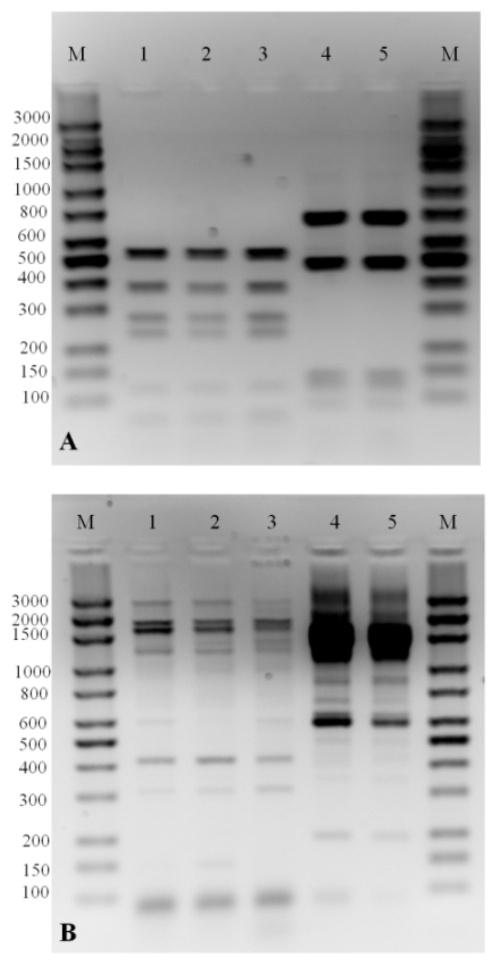
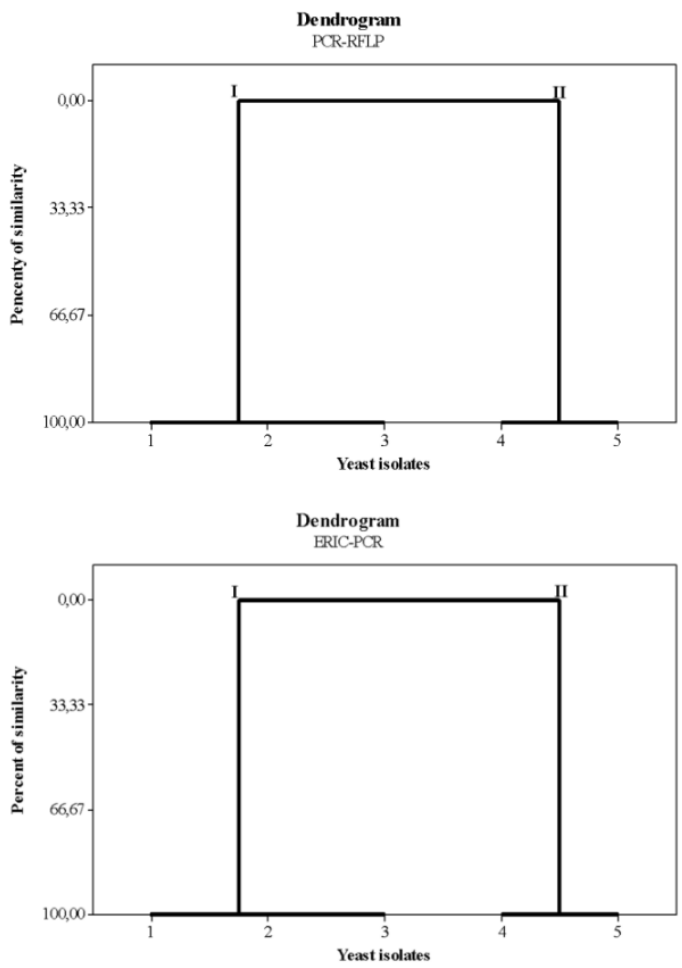

Figure 2. Characterization of genetic diversity among Candida species, isolated from pigeon feces, by PCRRFLP and ERIC-PCR methods. A. PCR-RFLP analysis. M: Mid-range molecular weight marker (Cellco Biotechnology). Rows 1 to 3: Candida krusei. Rows 4 and 5: Candida rugosa. B. Dendrogram of genetic relationship among yeast isolates using the PCR-RFL method for C. krusei and C. rugosa species. Isolates 1 to 5 were divided into two groups (I and II) according to the degree of similarity shown on the left side of the figure. C. ERIC-PCR analysis. M: Mid-range molecular weight marker (Cellco Biotechnology). Rows 1 to 3: C. krusei. Rows 4 and 5: C. rugosa. B. Dendrogram of the genetic relationship among yeast isolates using the ERIC-PCR method for $C$. krusei and C. rugosa species. Isolates 1 to 5 were divided into two groups (I and II) according to the degree of similarity shown on the left side of the Figure. 
Genotypic analysis of Candida species isolated in this study by the ERIC-PCR method yielded 18 distinct fragments (Figure 2C). The three C. krusei isolates shared the same band patterns $(50,100,125,140,240,290,390,500,550$ and $800 \mathrm{bp}$ ) as seen on $1.8 \%$ agarose gel (FIG. 2C). The two C. rugosa isolates had different profiles compared with the C. krusei isolates. However, C. rugosa isolates shared the same band pattern $(200,600,700$, 900, 1500, 2000, 3000 and $3500 \mathrm{bp)} \mathrm{(Figure} \mathrm{2C).} \mathrm{For} \mathrm{the} \mathrm{band} \mathrm{sharing} \mathrm{analysis,} \mathrm{bands} \mathrm{in}$ the range of 50-3500 bp were considered. The binary matrix created upon visual observation of the presence or absence of the fragments obtained after conduction of cluster analysis/calculation of the Euclidean distance generated a dendrogram showing the genetic diversity among isolates, as performed using the PCR-RFLP method. The five Candida species were divided into two groups (Group I and II) and distinct genotypes (Genotypes I and II) according to the degree of similarity (Figure 2D and Table 1).

\section{DISCUSSION}

Isolation of yeast from pigeon droppings has been previously reported (Costa et al., 2010; Medina et al., 2011; Wu et al., 2012; Soltani et al., 2013; Dou et al., 2017; Xavier et al., 2019). Medina et al. (2017) identified several Candida species (C. guilliermondii, $C$. albicans, C. rugosa, C. kefyr, S. cerevisiae, T. asahii) isolated from cloacal samples, and pigeon droppings collected from public squares. Candida species isolated from pigeon droppings are considered to be pathogenic for humans and animals, especially in immunedeficient people (Costa et al., 2010).

Candida krusei, one of the species found in the samples studied, has significant clinical importance because it is responsible for pathogenesis on humans. This yeast is described as a causative agent of fungal infections in susceptible patients, resulting in the lowest 90-day survival rates (53.6\%) among Candida. Although the prevalence of $C$. krusei among fungal infections remains low (2\%), its intrinsic resistance to fluconazole, low sensitivity to flucytosine and amphotericin B raises epidemiological and therapeutic concerns (Pfaller et al., 2008; Forasteiro et al., 2015; Xavier et al., 2019). Candida rugosa, also identified among the isolates of this study, is emerging yeast as an etiological agent of human infectious diseases in different parts of the world. In the last ten years, it has been described as a cause of candidemia in trauma patients (Medina et al., 2017; Xavier et al., 2019).

In recent years, the MALDI-TOF mass spectrometry method has proved to be a useful tool for quickly and accurately identifying bacteria and yeast at the species-level (Dou et al., 2017; Zhao et al., 2018; Xavier et al., 2019). In our research the MALDI-TOF method allowed the identification of isolated yeasts at the species level. However, the PCRRFLP and ERIC-PCR methods were used for the analysis of genetic diversity among yeast isolates.

Extragenic repetitive sequences such as the REP and ERIC elements are also used for identification of DNA from several bacterial species by PCR. Hierro et al. (2004) using ERIC-PCR, PCR-RFLP and REP-PCR methods, were successful in the identification and genetic characterization of yeasts yielding different patterns with 14 DNA fragments, ranging from 100 to 2000 base pairs.

Identification of yeast at the species level is considered difficult due to the variability among yeast species. The PCR-RFLP method can differentiate yeast species by 
using primers in conserved regions of the $18 \mathrm{~S}$ or $25 / 28 \mathrm{rRNA}$. Thus, using this method in clinical laboratories routine to differentiate Candida species is of paramount importance to ensure rapid and economic results (Trost et al., 2004). The diversity of new fungal species and antifungal resistance demonstrate the need for more specific, fast and cost-effective techniques since yeast were analyzed for morphological, biochemical and physiological properties (Fallahi et al., 2013).

Samples of urine, nails, skin and vaginal isolates from patients with Candida species were discriminated by the PCR/RFLP molecular method (Fallahi et al., 2013; Keikha et al., 2018; Fazeli et al., 2019). Fragments of 59 to 548 bp were obtained when using PCR-RFLP with restriction enzymes $A p a \mathrm{I}$ and BsiEI for analysis of C. krusei (Ge et al., 2012). Shokohi et al. (2010) analyzed Candida species using the RFLP method with the restriction enzyme MspI and obtained fragments of 510 to $879 \mathrm{bp}$, allowing the study of genetic diversity among isolates.

Benedetti et al. (2016) used in their study sequences from the ITS1 and ITS2 regions and the $5.8 \mathrm{~S}$ and $28 \mathrm{~S}$ rDNA genes that can correctly identify yeast species. The authors observed low intraspecific variability in Candida spp and high adaptability to different anatomical sites, likely explaining its high frequency in several samples from human hosts. The phylogenetic study showed that $C$. albicans isolates had low genetic diversity based on rDNA sequences, and the formation of two population groups was observed. The amplification of the ITS2-5.8S region was able to yield products of different sizes, ranging from 271 to 378 base pairs. The PCR/RFLP method was able to identify approximately 60 isolates of Candida species causing invasive infections (Robledo-Leal et al., 2018).

Knowledge of the epidemiology of Candida spp. contributes to the prevention and treatment of infections. Studies show that most individuals are colonized or infected by a single Candida strain, but the genetics of the species are defined according to the geographical area. Low genomic variability is predominant when an isolated strain of Candida is transmitted from one individual to another. Furthermore, intraspecific variability was not identified since individuals in the same location may be contaminated by a single yeast (Benedetti et al., 2016). The identification of the presence of genetic variability is necessary for studies on the epidemiology of microorganisms and their incidence; therefore, effective therapy could be administered to patients.

\section{CONCLUSIONS}

The MALDI-TOF method was able to identify yeast at the species level. PCRRFLP and ERIC-PCR methods produced similar results and were useful for genetic diversity analysis and interspecific differentiation of yeast strains in our study. However, both genotypic methods were not able to discriminate intra-specifically the two Candida species in our study, since they presented the same band pattern. To our knowledge these is the first research exploring molecular phylogenetic analysis to discriminate Candida strains in this Brazilian region. The genetic profiles established using the studied genomic methods will be used in the construction of an in-house database in the laboratory where this study was performed. The results of this study will be used to genetically characterize cryopreserved pathogenic yeast isolates found in the other locations sampled but not analyzed in this research. 


\section{ACKNOWLEDGMENTS}

The authors thank the Laboratory of Diagnosis of Aquatic Animal Diseases of the Ministry of Agriculture, Livestock and Supply, University of Minas Gerais, Brazil for their support in the MALDI-TOF proteomic analysis. The Unimontes Biotechnology PostGraduation Program.

\section{FUNDING}

Research supporting foundation of Minas Gerais State (FAPEMIG).

\section{CONFLICTS OF INTEREST}

The authors declare no conflict of interest.

\section{REFERENCES}

Assis GBN, Felipe LP, Alexandra UZ, Guilherme CT, et al. (2017). Use of MALDI-TOF mass spectrometry for the fast identification of Gram-positive fish pathogens. Front. Microbiol. 8: 1492.

Barbosa FS, Leite LN, Xavier MADS and Xavier AREDO (2019). Genomic and proteomic approach as a tool to discrimination of Escherichia coli strains of biotechnological interest. J. App. Biol. Biotech. 7(2): 48-54.

Bai FY (2014). Association of genotypes with infection types and antifungal susceptibilities in Candida albicans as revealed by recent molecular typing strategies. Mycology. 5: 1-9.

Bellemain E, Carlsen T, Brochmann C, Coissac E, et al. (2010). ITS as an environmental DNA barcode for fungi: An in silico approach reveals potential PCR biases. BMC Microbiol. 10: 189.

Benedetti VP, Savi DC, Aluizio R, Adamoski D, et al. (2016). Analysis of the genetic diversity of Candida isolates obtained from diabetic patients and kidney transplant recipients. Mem. Inst. Oswaldo Cruz 111: 417-422.

Chen LZ, Li YL and Yu YL (2014). Soil bacterial and fungal community successions under the stress of chlorpyrifos application and molecular characterization of chlorpyrifos-degrading isolates using ERIC-PCR. J. Zhejiang Univ. Sci. B. 15: 322-332.

Costa AKF, Sidrim JJC, Cordeiro RA, Brilhante RSN, et al. (2010). Urban pigeons (Columba livia) as a potential source of pathogenic yeasts: a focus on antifungal susceptibility of Cryptococcus strains in Northeast Brazil. Mycopathologia. 169: 207-213.

Dou H, Huizhu W, Shaowei X, Xinxin C, et al. (2017). Molecular characterization of Cryptococcus neoformans isolated from the environment in Beijing, China. Med. Mycol. 55: 737-747.

Doyle JJ and Doyle JL (1990) Isolation of plant DNA from fresh tissue. Focus. 12: 13-15.

Duan H, Chai T, Liu J, Zhang X, et al. (2009). Source identification of airborne Escherichia coli of swine house surroundings using ERIC-PCR and REP-PCR. Environ. Res. 109: 511-517.

Fallahi AA, Korbacheh P, Zaini F, Mirhendi H, et al. (2013). Candida species in cutaneous candidiasis patients in the Guilan province in Iran; identified by PCR-RFLP method. Acta Med. Iran. 51: 799-804.

Fatima A, Bashir G, Wani T, Jan A, et al. (2017). Molecular identification of Candida species isolated from cases of neonatal candidemia using polymerase chain reaction-restriction fragment length polymorphism in a tertiary care hospital. Indian J. Pathol. Microbiol. 60: 61-65.

Fazeli A, Kordbacheh P, Nazari A, Daie-Ghazvini R, et al. (2019). Candiduria in hospitalized patients and identification of isolated Candida species by morphological and molecular methods in Ilam, Iran. Iran. J. Public Health 48: 156161.

Forastiero A, Garcia-Gil V, Rivero-Menendez O, Garcia-Rubio R, et al. (2015). Rapid development of Candida krusei echinocandin resistance during caspofungin therapy. Antimicrob. Agents Chemother. 59: 6975-6982.

Gaskin JM, Wilson HR, Mather FB, Jacob JP, et al. (2013). Enfermedades de las Aves Transmisibles a los Humanos. Univ. Florida 6: Available at [https://ufdcimages.uflib.ufl.edu/IR/00/00/16/18/00001/AN09900.pdf]. Accessed Oct. 12, 2019.

Ge YP, Wang L, Lu GX, Shen YN, et al. (2012). A simple and reliable PCR-restriction fragment length polymorphism assay to identify Candida albicans and its closely related Candida dubliniensis. Braz. J. Microbiol. 43: 873-879. 
Gharaghani M, Ahmadi B, Sisakht MT, Ilami O, et al. (2018). Identification of Candida species isolated from vulvovaginal candidiasis patients by polymerase chain reaction-restriction fragment length polymorphism (PCRRFLP) in Yasuj southwestern Iran. Jundishapur J. Microbiol. 11: e65359.

Gillings M and Holley M (1997). Repetitive element PCR fingerprinting (rep-PCR) using enterobacterial repetitive intergenic consensus (ERIC) primers is not necessarily directed at ERIC elements. Lett. Appl. Microbiol. 25: 17-21.

Hierro N, González Á, Mas A and Guillamón JM (2004). New PCR-based methods for yeast identification. J. Appl. Microbiol. 97: 792-801.

Isik N, White L, Barnes R, Poynton CJ, et al. (2003). A simple PCR/RFLP analysis can differentiate between Candida albicans, Aspergillus niger, and Aspergillus fumigatus. Mol. Biotechnol. 24: 229-231.

Jafari Z, Motamedi M, Jalalizand N, Shokoohi GR, et al. (2017). Comparison between CHROMagar, PCR-RFLP and PCR-FSP for identification of Candida species. Curr. Med. Mycol. 3: 10-15.

Keikha N, Shafaghat M, Mousavi SM, Moudi M, et al. (2018). Antifungal effects of ethanolic and aqueous extracts of Vitex agnus-castus against vaginal isolates of Candida albicans. Curr. Med. Mycol. 4: 1-5.

Medina IR, Fuentes LR, Arteaga MB, Valcárcel FR, et al. (2017). Pigeons and their droppings as reservoirs of Candida and other zoonotic yeasts. Rev. Iberoam. Micol. 34: 211-214.

Mirhendi H, Makimura K, Khoramizadeh M and Yamaguchi H (2006). A one-enzyme PCR-RFLP assay for identification of six medically important Candida species. Jpn. J. Med. Mycol. 47: 225-229.

Mohammadi R, Badiee P, Badali H, Abastabar M, et al. (2015). Use of restriction fragment length polymorphism to identify Candida species, related to onychomycosis. Adv. Biomed. Res. 4: 95

Patel R (2015). MALDI-TOF MS for the diagnosis of infectious diseases. Clin. Chem. 61: 100-111.

Pfaller MA, Diekema DJ, Gibbs DL, Newell VA, et al. (2008). Candida krusei, a multidrug-resistant opportunistic fungal pathogen: geographic and temporal trends from the ARTEMIS DISK Antifungal Surveillance Program, 2001 to 2005. J. Clin. Microbiol. 46: 515-521.

Raja HA, Miller AN, Pearce CJ and Oberlies NH (2017). Fungal identification using molecular tools: a primer for the natural products research community. J. Nat. Prod. 80: 756-770.

Robledo-Leal E, Rivera-Morales LG, Sangorrín MP, González GM, et al. (2018). Identification and susceptibility of clinical isolates of Candida spp. to killer toxins. Braz. J. Biol. 78: 742-749.

Shokohi T, Hashemi Soteh MB, Pouri ZS, Hedayati MT, et al. (2010). Identification of Candida species using PCRRFLP in cancer patients in Iran. Indian J. Med. Microbiol. 28: 147-151.

Soltani M, Mansour B, Seyed JH, Mohammadali Z, et al. (2013). Isolation of Cryptococcus neoformans and other opportunistic fungi from pigeon droppings. J. Res. Med. Sci. 18: 56-60.

Trost A, Graf B, Eucker J, Sezer O, et al. (2004). Identification of clinically relevant yeasts by PCR/RFLP. J. Microbiol. Methods 56: 201-211.

Wu Y, Peng-Cheng D, Wen-Ge L and Jin-Xing L (2012). Identification and molecular analysis of pathogenic yeasts in droppings of domestic pigeons in Beijing, China. Mycopathologia. 174: 203-214.

Xavier AREO, Cardoso L, Brito RVJ, Nobre SAM, et al. (2019). Detection and identification of medically important microorganisms isolated from pigeon excreta collected in a university in a newly industrialized country. Biotemas. 32: 11-20.

Yuan W, Chai TJ and Miao ZM (2010). ERIC-PCR identification of the spread of airborne Escherichia coli in pig houses. Sci. Total Environ. 408: 1446-1450.

Zhao Y, Tsang CC, Xiao M, Chan JFW, et al. (2018). Yeast identification by sequencing, biochemical kits, MALDITOF MS and REP-PCR DNA fingerprinting. Med. Mycol. 56: 816-827. 